\title{
Iodination of Antibodies with Immobilized lodogen
}

\author{
Eric A. Berg and Jordan B. Fishman
}

Iodination, a chemical or enzymatic incorporation of ${ }^{125} \mathrm{I}$ to specific amino acid side chains, is a commonly used method for labeling antibodies with radioisotopes. Commercially available products make iodination of antibodies a simple and quick process. One example, used here and available at Pierce, is the "Iodination bead," or $N$-chloro-benzenesulfonamide immobilized on nonporous, polystyrene beads.

It is essential that you consult the appropriate Material Safety Data Sheets and your institution's Environmental Health and Safety Office for proper handling of equipment and hazardous materials used in this protocol.

Reagents

Antibody of interest

Iodination beads (Pierce)

This oxidizing agent was first reported by Markwell (1982) as a means for iodinating proteins.

Phosphate $(0.1 \mathrm{M})$ and $\mathrm{NaCl}(0.15 \mathrm{M}, \mathrm{pH} 7.2)$

Sodium iodide $\left(\mathrm{Na}^{125} \mathrm{I}\right)$, carrier-free

Equipment

Desalting column (G-25)

1. Immediately before use, wash beads with $500 \mu \mathrm{L}$ of $0.1 \mathrm{~m}$ phosphate, $0.15 \mathrm{M} \mathrm{NaCl}$ ( $\mathrm{pH}$ 7.2) per bead. Dry the beads on filter paper.

2. Add two beads to a solution of carrier-free $\mathrm{Na}^{125} \mathrm{I}(\sim 1 \mathrm{mCi}$ per $100 \mu \mathrm{g}$ of protein) diluted with $0.1 \mathrm{~m}$ phosphate, $0.15 \mathrm{~m} \mathrm{NaCl}$ ( $\mathrm{pH}$ 7.2). Incubate for $5 \mathrm{~min}$.

3. Dissolve or dilute the antibody to $1 \mathrm{mg} / \mathrm{mL}$ in $0.1 \mathrm{~m}$ phosphate, $0.15 \mathrm{M} \mathrm{NaCl}$ ( $\mathrm{pH} 7.2$ ), and add to the beads.

4. Incubate the reaction mixture for $2-15 \mathrm{~min}$. The incubation time will depend on the sensitivity of the antibody to oxidation.

5. Stop the reaction by removing the solution from the reaction vessel.

From the Antibodies collection, edited by Edward A. Greenfield.

(C) 2020 Cold Spring Harbor Laboratory Press

Cite this protocol as Cold Spring Harb Protoc; doi:10.1101/pdb.prot099341 
E.A. Berg and J.B. Fishman

6. Wash the beads with $100 \mu \mathrm{L}$ of $0.1 \mathrm{~m}$ phosphate, $0.15 \mathrm{M} \mathrm{NaCl}(\mathrm{pH} 7.2$ ). Add the wash to the antibody solution in Step 5.

7. Desalt the antibody solution using a G-25 filtration column.

8. Store the antibody at $4^{\circ} \mathrm{C}$. Use within $60 \mathrm{~d}$ for the desired application.

See Troubleshooting.

\section{TROUBLESHOOTING}

Problem (Step 8): There is a low level of iodination because of poor or no tyrosine availability. Solution: Use a different method of iodination (e.g., Bolton-Hunter Reagent).

Problem (Step 8): There is no iodination. The antibody is contaminated with reducing agents. Solution: Dialyze the antibody extensively.

Problem (Step 8): There is low protein recovery. The antibody is sensitive to oxidation. Solution: Use a shorter time for the labeling reaction (Step 4).

\section{REFERENCES}

Markwell MA. 1982. A new solid-state reagent to iodinate proteins. I. Conditions for the efficient labeling of antiserum. Anal Biochem 125: 427-432. 


\section{lodination of Antibodies with Immobilized lodogen}

Eric A. Berg and Jordan B. Fishman

Cold Spring Harb Protoc; doi: 10.1101/pdb.prot099341

\begin{tabular}{cc}
$\begin{array}{r}\text { Email Alerting } \\
\text { Service }\end{array}$ & Receive free email alerts when new articles cite this article - click here. \\
\hline $\begin{array}{c}\text { Subject } \\
\text { Categories }\end{array}$ & $\begin{array}{c}\text { Browse articles on similar topics from Cold Spring Harbor Protocols. } \\
\text { Antibodies (119 articles) } \\
\text { Antibodies, general (289 articles) } \\
\text { Handling Antibodies (43 articles) } \\
\text { Labeling Antibodies (16 articles) }\end{array}$ \\
\hline
\end{tabular}

